\title{
Family conference in palliative care: concept analysis
}

\author{
Conferência familiar em cuidados paliativos: análise de conceito \\ Conferencia familiar en cuidados paliativos: análisis de concepto
}

\section{Rudval Souza da Silva', Géssica Sodré Sampaio Trindade', Gilvânia Patrícia do Nascimento Paixão', Maria Júlia Paes da Silva"}

'Universidade do Estado da Bahia, Collegiate Nursing. Senhor do Bonfim, Bahia, Brazil.

"Universidade de São Paulo, School of Nursing, Department of Medical-Surgical Nursing. São Paulo, Brazil.

How to cite this article:

Silva RS, Trindade GSS, Paixão GPN, Silva MJP. Family conference in palliative care: concept analysis.

Rev Bras Enferm [Internet]. 2018;71(1):206-13. DOI: http://dx.doi.org/10.1590/0034-7167-2016-0055

Submission : 03-15-2016 Approval: 03-06-2017

\begin{abstract}
Objective: to analyze the attributes, antecedents and consequents of the family conference concept. Method: Walker and Avante's method for concept analysis and the stages of the integrative review process, with a selection of publications in the PubMed, Cinahl and Lilacs databases focusing on the family conference theme in the context of palliative care. Results: the most cited antecedents were the presence of doubts and the need to define a care plan. Family reunion and working instrument were evidenced as attributes. With respect to consequents, to promote the effective communication and to establish a plan of consensual action were the most remarkable elements. Final considerations: the scarcity of publications on the subject was observed, as well as and the limitation of the empirical studies to the space of intensive therapy. Thus, by analyzing the attributes, antecedents and consequents of the concept it was possible to follow their evolution and to show their efficacy and effectiveness as a therapeutic intervention.
\end{abstract}

Descriptors: Palliative Care; Consensus Conference; Family; Communication; Concept Formation.

\section{RESUMO}

Objetivo: analisar os atributos, antecedentes e consequentes do conceito conferência familiar. Método: o estudo seguiu o Modelo de Análise de Conceito de Walker e Avante e os passos da revisão integrativa, com seleção de publicações nas bases de dados PubMed, Cinahl e Lilacs, com o foco na temática conferência familiar no contexto dos cuidados paliativos. Resultados: os antecedentes mais citados foram presença de dúvidas e necessidade de definição de um plano de cuidados. Como atributos foram evidenciados reunião familiar e instrumento de trabalho. Com relação aos consequentes, promover a comunicação eficaz e estabelecer um plano de atuação consensual foram os elementos mais marcantes. Considerações finais: possibilitou evidenciar a escassez de publicações sobre a temática e os estudos empíricos restritos ao espaço da terapia intensiva. Assim, analisar os atributos, os antecedentes e os consequentes do conceito possibilitou acompanhar sua evolução e evidenciar a sua eficácia e efetividade enquanto intervenção terapêutica.

Descritores: Cuidados Paliativos; Conferência de Consenso; Família; Comunicação; Formação de Conceito.

\section{RESUMEN}

Objetivo: analizar los atributos, antecedentes y consecuentes del concepto conferencia familiar. Método: el estudio siguió el Modelo de Análisis de Concepto de Walker y Avante y los pasos de la revisión integradora, con selección de publicaciones en las bases de datos PubMed, Cinahl y Lilacs, con el foco en la temática conferencia familiar en el contexto de los cuidados paliativos. Resultados: los antecedentes más citados fueron presencia de dudas y necesidad de definición de un plan de cuidados. Como atributos fueron evidenciados reunión familiar e instrumento de trabajo. Con relación a los consecuentes, promover la comunicación eficaz y establecer un plan de actuación consensual fueron los elementos más marcados. Consideraciones finales: posibilitó evidenciar la escasez de publicaciones sobre la temática y los estudios empíricos restrictos al espacio de la terapia intensiva. Así, analizar los atributos, los antecedentes y los consecuentes del concepto posibilitó acompañar su evolución y evidenciar su eficacia y efectividad en cuanto intervención terapéutica.

Descriptores: Cuidados Paliativos; Conferencia de Consenso; Familia; Comunicación; Formación de Concepto. 


\section{INTRODUCTION}

Caring is the essence of the philosophical principles of palliative care, being the guiding thread of the knowledge structure of professionals working in this field, regardless of the environment in which the patient is. In concomitance with caring for a person with an incurable, progressive and life-threatening illness, there is a need for special attention to their families, considering the person and his / her family as a care unit ${ }^{(1)}$.

This perspective is also acknowledged by the World Health Organization (WHO), which defines palliative care as caring practices developed by an interdisciplinary team, with the objective of improving the quality of life of the patient and his/ her family, through prevention and suffering relief, early identification, careful evaluation, and treatment of pain as well as other physical, social, psychological and spiritual symptoms ${ }^{(2)}$. Therefore, it is possible to infer that the WHO itself, in its definition of palliative care, recognizes that the family also requires care, given the socio-emotional impact it experiences during the follow-up of loved ones in the termination process ${ }^{(3)}$.

The success of patient and family care depends on how the team supports this care $u_{n i t}{ }^{(3)}$. It is important to have an interdisciplinary integration, even considering that each care requires the presence of a team member that is directly involved in the situation, the so-called "case manager". This will be the main link of communication with the family, which is valued by the family members, mainly for enabling a bond of trust, thereby avoiding contradictory information ${ }^{(4)}$. It is worth mentioning that, regardless of the role of the "case manager", other team members can and should collaborate in providing support to the family whenever necessary.

Thus, communication is such a central element in the context of palliative care ${ }^{(5-6)}$ that it is necessary to make it effective among team members, patients and families. As a result, conflicts are expected to decrease, preventing misunderstandings, and solving detected problems to better quality of life for the patient and his family ${ }^{(1)}$.

Developing communication skills is a determining factor in promoting a safe and secure environment in the face of difficult situations, especially when it comes to caring for people experiencing terminality ${ }^{(6)}$. It is essential to have some knowledge about the needs, doubts, anxieties and fears presented by the family, with a view to a better orientation in the planning of the care. To this end, the palliative care team must maintain a partnership between the patient and his family.

Effective communication favors means of helping patients to clarify their problems and to better face them with active participation in the decision-making process and in the search for alternatives to solutions to real or potential problems as well as assists in the development of new patterns of behavior, thereby re-signifying their life ${ }^{(6)}$.

Caring for a sick and terminally ill person represents a family overload, since, in addition to all socio-emotional difficulties, it also causes physical exhaustion. Faced with all the fatigue, fear and doubts the conspiracy of silence usually emerges and, in some situations, misunderstandings that generate conflicts, which tends to contribute to the difficulties of intra-family relationships, interfering in the progress and evolution of the prognosis of the patient. Therefore, it is the responsibility of the health professional to intervene such conflicts or resolve doubts, in order to improve the quality of life for the patient and his family, even if they are often reluctant because they either consider it a time-consuming task, do not feel prepared for it ${ }^{(3)}$.

Thus, the need to hold a family conference, a therapeutic instrument used by the palliative care team, emerges as a moment of planned dialogue between patient, family and team ${ }^{(7)}$. Although it is of particular importance, the family conference is still less widespread among health professionals ${ }^{(7-8)}$. And, in the case of publications by nursing professionals, none was found in the databases visited, during the survey of excellence on the subject, nor was there evidence of already completed revisions focusing on this theme.

In addition to the scarcity of studies, it can be seen that there is no single definition in the literature about family conferences ${ }^{(3,7)}$. For some authors, family conference is defined as an intervention aimed at sharing information, clarifying doubts about patient and family concerns, and communicating "bad news" in order to allow the family not only to understand the dynamics of the care that is being provided to their loved one in the process of dying, but also establish an affective connection so that it is possible to reach a consensus in the resolution of problems ${ }^{(7)}$.

Another study states that the family conference reflects a planned intervention with the family with the goal of helping to alleviate suffering. It is an effective means of communication and should be structured to enable nurses and other health professionals to provide information, assess patient and family needs, and create opportunities for shared decisionmaking for interaction within the family ${ }^{(3)}$.

It is necessary to develop a concept analysis about the family conference in the context of palliative care, aiming at a better understanding and of the concept, and enabling a practical systematization of this therapeutic family instrument.

Concept analysis is an intellectual activity whose purpose is to clarify a concept of interest. Due to the dynamic evolution of scientific knowledge over time, the need to analyze the concepts of interest for everyday practice emerges, since it is expected that, through such analysis, it will be possible to allow exchanges of knowledge and better explain the essence of Nursing; in this case, in the context of the palliative care team ${ }^{(9)}$.

Concept analysis is an intellectual activity whose purpose is to clarify a concept of interest. Because of the dynamic evolution of scientific knowledge over time, the need to analyze the concepts of interest for everyday practice emerges, since it is expected that, through such analysis, it will be possible to allow exchanges of knowledge and better explain the essence of Nursing; in this case, in the context of the palliative care team ${ }^{(9)}$.

In view of the above, the following question emerged: What are the attributes, antecedents and consequents of the concept of family conference in the context of palliative care?

\section{OBJECTIVE}

To analyze the attributes, antecedents and consequents of the family conference concept in the context of palliative care. 


\section{METHOD}

\section{Ethical aspects}

For this study, only the literature was used as a data source for the survey of the attributes, antecedents and consequents of the concept "family conference". Under this perspective, it does not constitute a study involving human beings and, therefore, was not submitted to the Ethics and Research Committee.

\section{Theoretical-methodological reference}

As a theoretical-methodological reference, the concept analysis model proposed by Walker and Avant ${ }^{(10)}$ was adopted. This method proposes an interactive process throughout the research with the purpose of analyzing the structure and function of the basic elements of a certain concept, with the purpose of distinguishing it, refining ambiguities and clarifying vague and relevant concepts about Nursing, in order to develop the validation of the construct and contribute to the development of Nursing practice ${ }^{(10)}$.

The model adopted consists of eight stages: choosing the concept, determining the purpose of the analysis, identifying the uses of the concept, determining the defining attributes, identifying model cases, identifying additional cases, identify antecedents and consequents, and to determining the empirical references.

\section{Type of study}

This is a methodological study, with a qualitative approach, which aimed to analyze the concept of "family conference" based on the concept analysis model of Walker and Avant ${ }^{(10)}$.

\section{Methodological procedures}

\section{Scenario of the study}

The identification of the concept of "family conference" was considered as an essential element in the context of palliative care, with the communication process as one of its pillars. Thus, the study aims to clarify the meaning of the existing concept in favor of its use as an instrument of therapeutic intervention in the practice of palliative care and as a phenomenon of interest to the Nursing area, thereby enabling the amplification of its compression by the palliative nurses.

In this study, the following steps were performed: concept selection, delimitation of the objectives of the analysis, determination of critical or essential attributes, as well as background and consequent identification of the concept under analysis - corresponding to steps 1, 2, 4 and 7 proposed by the authors ${ }^{(10)}$, respectively.

The selection of these four steps was based on the understanding that they are satisfactory to meet the objective of the present study, considering that the other steps indicated in the model $^{(10)}$ aim to establish categories from the phenomenon observed, which is not part of the present objective. Thus, the concept "family conference" was chosen, with the objective of analyzing it in the context of palliative care and identifying its antecedents, and critical and consequent attributes.

\section{Collection and organization of data}

The selection of the articles was carried out by searching the following databases: PubMed (Public / Publish Medline),
Cinahl (Cumulative Index to Nursing and Allied Health Literature) and Lilacs (Latin American and Caribbean Literature in Health Sciences). In order to ensure a careful search, the controlled descriptors (MeSH Database, Cinahl Headings and Descriptors in Health Sciences) and uncontrolled ones (keywords) were delimited according to each database. The Palliative care descriptor delimited for search was combined with the uncontrolled descriptors (Conference family; Family meetings). For example, palliative care AND conference family $O R$ family meetings. In Lilacs, the controlled descriptor was combined according to the database, for example, palliative care $A N D$ family conference $O R$ family reunion.

The criteria for inclusion of articles defined for this review were: 1 ) to be a complete research article about family conference; 2) articles in English, Spanish or Portuguese, with no limit on the year of publication; 3) articles available electronically. Response letters and editorials were deleted. The search was performed by online access, in April 2015, and resulted in a final sample of 13 articles, published between the years of 2002 and 2015 (Table 1).

The conduction of the integrative review allowed us to survey, evaluate and gather the selected primary studies, making it possible to follow the steps of the methodological framework adopted - concept analysis ${ }^{(10)}$. The selected articles were subjected to careful reading, allowing us to identify and list the critical antecedent and consequent attributes of the concept under analysis, as presented below in the form of figure in the item results and discussed based on the literature.

Table 1 - Articles selected per database after initial evaluation

\begin{tabular}{lcccc}
\hline \multicolumn{1}{c}{ Evaluation } & PubMed & Cinahl & Lilacs & Total \\
\hline Total found & 169 & 98 & 24 & 291 \\
Repeated & 87 & 60 & 16 & 163 \\
Not a full Research article & 56 & 13 & 2 & 71 \\
Does not meet the objective & 9 & 17 & 2 & 28 \\
Unavailable electronically & 11 & 4 & 1 & 16 \\
Total selected & 6 & 4 & 3 & 13 \\
\hline
\end{tabular}

\section{Data analysis}

The determination of the critical or essential attributes aims at differentiating a specific phenomenon from similar ones, being considered the core of concept analysis, insofar as it reveals the characteristics that appear more frequently associated to the concept ${ }^{(10)}$. To identity the attributes of the concept under study, the following questions were established for data analysis, How is the concept defined by the authors? What are the characteristics or attributes pointed out? What do the authors think and discuss about the family conference?

The identification of antecedents and consequents of the concept aims to understand the social context in which the concept is used, based on the survey of incidents or events that occur a priori and a posteriori to the phenomenon ${ }^{(10)}$. To 
support the investigation of the antecedents and consequences of the concept, we made an attempt to answer the following questions, What events, situations and or phenomena contribute to the evidence of the need to hold a family conference? What is the outcome of a family conference?

To determine the critical attributes and identify antecedents and consequents of the concept, an integrative review of the literature was carried out, which went through the following stages: problem formulation, data collection, data evaluation, data analysis and interpretation, and results dissemination of results ${ }^{(11)}$.

\section{RESULTS}

A total of 291 publications were identified, of which 278 were excluded because of the following reasons: repetition, incomplete research article, unavailable electronically or not meeting the study objective. Thus, thirteen studies were included in the integrative review phase, which supported the stages of Concept Analysis and are presented in Chart 1, with respective levels of evidence.

The analysis of the articles that composed the selected sample enabled the identification of the antecedents, attributes and consequents of the family conference concept, shown in Figure 1.

Chart 1 - Summary of studies included in the integrative review phase $(n=13), 2015$

\begin{tabular}{|c|c|c|c|c|}
\hline Authorship & $\begin{array}{l}\text { Year / country / } \\
\text { database }\end{array}$ & $\begin{array}{l}\text { Type of study / } \\
\text { evidence level (EL) }\end{array}$ & Language & Objective \\
\hline Galriça Neto I (3) & $\begin{array}{l}2009 \\
\text { Portugal } \\
\text { Lilacs }\end{array}$ & $\begin{array}{l}\text { Expert Opinion } \\
\qquad E L=6\end{array}$ & Portuguese & $\begin{array}{l}\text { Present the main guidelines for holding } \\
\text { the family conference }\end{array}$ \\
\hline Galriça Neto I, Trindade $\mathrm{N}^{(4)}$ & $\begin{array}{l}2009 \\
\text { Portugal } \\
\text { Lilacs }\end{array}$ & $\begin{array}{l}\text { Expert Opinion } \\
\qquad E L=6\end{array}$ & English & $\begin{array}{l}\text { Discuss family conference use as a tool } \\
\text { used by health professionals to provide } \\
\text { support to family patients }\end{array}$ \\
\hline Fineberg IC ${ }^{(7)}$ & $\begin{array}{c}2005 \\
\text { EUA } \\
\text { PubMed }\end{array}$ & $\begin{array}{l}\text { Longitudinal cohort } \\
\text { study } \\
\mathrm{EL}=3\end{array}$ & English & $\begin{array}{l}\text { Assess students' ability to lead a family } \\
\text { conference }\end{array}$ \\
\hline $\begin{array}{l}\text { Hudson P, Quinn K, O'Hanlon } \\
\text { B, Aranda S }\end{array}$ & $\begin{array}{l}2008 \\
\text { Austrália } \\
\text { PubMed }\end{array}$ & $\begin{array}{l}\text { Systematic review } \\
\qquad E L=1\end{array}$ & English & $\begin{array}{l}\text { Develop multidisciplinary clinical practice } \\
\text { guidelines to conduct a family conference }\end{array}$ \\
\hline $\begin{array}{l}\text { Hudson P, Thomas T, Quinn K, } \\
\text { Aranda } S^{(12)}\end{array}$ & $\begin{array}{l}2009 \\
\text { Austrália } \\
\text { PubMed }\end{array}$ & $\begin{array}{c}\text { Randomized clinical } \\
\text { trial } \\
\mathrm{EL}=2\end{array}$ & English & $\begin{array}{l}\text { Evaluate clinical guidelines in conducting } \\
\text { a family conference }\end{array}$ \\
\hline $\begin{array}{l}\text { Fineberg IC, Kawashima M, Asch } \\
\qquad \mathrm{SM}^{(13)}\end{array}$ & $\begin{array}{l}2011 \\
\text { Reino Unido } \\
\text { Cinahl }\end{array}$ & $\begin{array}{l}\text { Case study } \\
\qquad E L=5\end{array}$ & English & $\begin{array}{l}\text { Develop a template for family } \\
\text { conferencing }\end{array}$ \\
\hline $\begin{array}{c}\text { Curtis JR, Engelberg RA, } \\
\text { Wenrich MD, Nielsen EL, } \\
\text { Shannon SE, Treece PD, et al }{ }^{(14)}\end{array}$ & $\begin{array}{c}2002 \\
\text { EUA } \\
\text { PubMed }\end{array}$ & $\begin{array}{l}\text { Systematic review } \\
\qquad \mathrm{El}=1\end{array}$ & English & $\begin{array}{l}\text { Develop an understanding of how family } \\
\text { conferences are conducted }\end{array}$ \\
\hline DeLisser $\mathrm{HM}^{(15)}$ & $\begin{array}{c}2010 \\
\text { EUA } \\
\text { PubMed }\end{array}$ & $\begin{array}{l}\text { Case study } \\
\qquad E L=5\end{array}$ & English & $\begin{array}{l}\text { Present the family conference as a } \\
\text { possibility to discuss the limits of life }\end{array}$ \\
\hline Joshi $\mathrm{R}^{(16)}$ & $\begin{array}{l}2013 \\
\text { EUA } \\
\text { CINAHL }\end{array}$ & $\begin{array}{l}\text { Case study } \\
\qquad \mathrm{EL}=5\end{array}$ & English & $\begin{array}{l}\text { Discuss clinical case from family } \\
\text { conference perspective }\end{array}$ \\
\hline Moneymaker $\mathrm{K}^{(17)}$ & $\begin{array}{c}2005 \\
\text { EUA } \\
\text { PubMed }\end{array}$ & $\begin{array}{l}\text { Case study } \\
\qquad \mathrm{EL}=6\end{array}$ & English & Present a protocol for a family conference \\
\hline $\begin{array}{l}\text { Gay EB, Pronovost PJ, Bassett } \\
\text { RD, Nelson JE }{ }^{(18)}\end{array}$ & $\begin{array}{l}2009 \\
\text { EUA } \\
\text { Lilacs }\end{array}$ & $\begin{array}{l}\text { Case study } \\
\qquad E L=6\end{array}$ & English & $\begin{array}{c}\text { Discuss practical strategies to overcome } \\
\text { barriers at a family conference }\end{array}$ \\
\hline $\begin{array}{c}\text { Powazki R, Walsh D, Hauser K, } \\
\text { Davis MP(19) }\end{array}$ & $\begin{array}{l}2004 \\
\text { EUA } \\
\text { Cinahl }\end{array}$ & $\begin{array}{l}\text { Randomized clinical } \\
\text { trial } \\
\mathrm{EL}=2\end{array}$ & English & $\begin{array}{l}\text { Describe the burden of family care and } \\
\text { review the responsibilities of doctors to } \\
\text { family caregivers }\end{array}$ \\
\hline $\begin{array}{l}\text { Sullivan SS, Silva CFR, Meeker } \\
\qquad \mathrm{MA}^{(20)}\end{array}$ & $\begin{array}{l}2015 \\
\text { EUA } \\
\text { Cinahl }\end{array}$ & $\begin{array}{l}\text { Systematic review } \\
\qquad E L=1\end{array}$ & English & $\begin{array}{c}\text { Examine and synthesize available } \\
\text { evidence about the family conference on } \\
\text { end-of-life care }\end{array}$ \\
\hline
\end{tabular}




\section{FAMILY CONFERENCE IN PALLIATIVE CARE}

\begin{tabular}{|c|c|c|}
\hline ANTECEDENTS & ATRIBUTES & CONSEQUENTS \\
\hline $\begin{array}{l}\text { - Decision-making process }{ }^{(13-14,17)} \\
\text { - Definition of a care plan }{ }^{(3-4,8,14,18)} \\
\text { - Intrafamilial conflicts }{ }^{(3-4)} \\
\text { - } \text { Doubts (advantages and disadvantages of } \\
\text { therapy) })^{(3-4,8,12-14,19-20)} \\
\text { - Clarification on goals } s^{(8,12,19-20)} \\
\text { - Anguish }{ }^{(3-1,17)} \\
\text { - Perspectives vis-à-vis illness and death }{ }^{(3-4,15,17)} \\
\text { - } \text { A Worsening of the clinical picture }{ }^{(3-4)} \\
\text { - Proximity of death }{ }^{(3-4,17)} \\
\text { - Difficulty in communication } \\
\text { - Need to support the family }{ }^{(3-4,7)}\end{array}$ & $\begin{array}{l}\text { - Working instrument }{ }^{(3-4,8,12,17)} \\
\text { - Integration strategy } y^{(8,12)} \\
\text { - Method of communication }{ }^{(7,15)} \\
\text { - Family intervention }{ }^{(3-4,13,17)} \\
\text { - Information sharing }{ }^{(12-14)} \\
\text { - Transmission of information }{ }^{(3-4,8,12,14)} \\
\text { - Discussion forum (doubts, prognosis and } \\
\text { care preferences) })^{(12,15,19-20)} \\
\text { - Family meeting to establish care } \\
\text { plans } s^{(3-4,7,13-14,16-17,20)} \\
\text { - Demonstration of appreciation and respect } \\
\text { for the family }\end{array}$ & 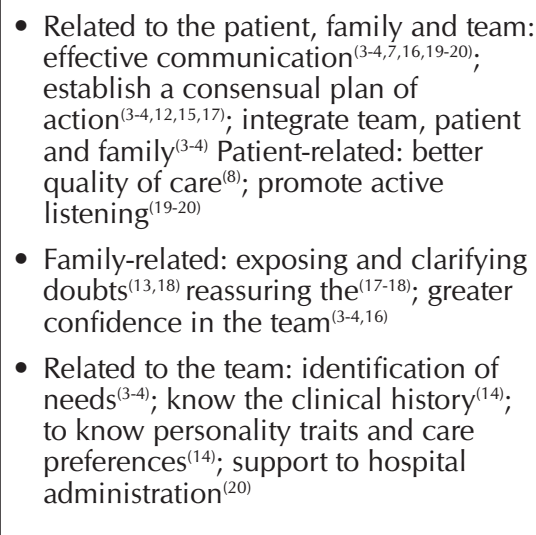 \\
\hline
\end{tabular}

Figure 1 - Antecedents, attributes and consequences of the family conference concept

\section{DISCUSSION}

\section{Antecedents of the family conference concept}

Among the aforementioned antecedents, the most present element in the analyzed articles refers to the doubts related to the decision making regarding the use or not of the therapeutic conducts in function of its advantages and disadvantages. Studies ${ }^{(3-4)}$ show that, with the proximity of death, issues such as fear of the unknown, myths, uncertainties due to the prognosis related to a life-threatening disease, and doubts about the modifying therapy of the disease, and if this brings benefits or only protects the process of dysthanasia.

This is corroborated by the studies analyzed ${ }^{(8,12-13)}$, which show, among the indications for a family reunion, that of the need to identify what the family already knows about the patient's prognosis and whether there are gaps and doubts to be resolved.

With the family conference it is possible, through active listening, to clarify doubts, discuss feelings and reduce the psychosocial anxieties present ${ }^{(8)}$. To address the doubts of patients and their families is to respect the autonomy of the other and to offer them the possibility of choices, fulfilling what is proposed in the philosophical principles of palliative care presented by $\mathrm{WHO}$ in meeting the effective needs of support to families ${ }^{(12-13)}$. Thus, it is evident that the family should be cared for by the team as much as the patient.

Support in the decision-making process was another antecedent evidenced in the studies ${ }^{(13-15)}$. It was possible to confirm that, in order to provide due support for decision-making, negotiation is an essential element in a family conference, as a component of the communication process and assimilation from the point of view of the other, favoring a decision with respect, especially to patient autonomy ${ }^{(13)}$.

In this negotiation scenario, nurses have a determining role in intermediating palliative care team, patient and family. A study conducted with intensive care physicians analyzed the communication process during 50 family conferences held at four ICUs; the importance of nurses' participation in the communication process for decision-making during a family conference was highlighted ${ }^{(14)}$.

Seen as the professionals who spends the most time with the patients ${ }^{(1)}$, therefore being in a privileged position in care provision, nurses can intermediate the communication process among patient, family and health team, thereby contributing to enhancing the flow of communication and favoring subsidies in the decision-making process, when the family conference is held.

A study ${ }^{(6)}$ that addresses interpersonal communication strategies among palliative nurses evidenced improvement of communication skills in order to allow better attention to the emotional dimension of care, as they used words of an emotional and affective nature during the therapeutic interventions.

In addition to the need for negotiation, a study ${ }^{(15)}$ shows that empathy is an essential element for the identification of the antecedent "decision-making process" because it allows detecting the emotions and feelings expressed by the patient and family, as well as recognizing the need for family conference.

The antecedent "intra-family conflict" "(3-4) appears as an indicator of situations in which many family members are involved in care and there is no consensus of opinion on decisions to be taken, such as a dilemma about keeping the patient at home or hospitalized. Such studies show that intra-family conflict situations call for a family reunion with the support of the health team, in which it must negotiate with the family, respecting the patient's wishes and establishing a consensual plan of actions including the patient, family and team. It is important to make written notes of the points discussed and the agreed plan, especially when there are indications of situations where there is obvious conflict.

In view of these considerations, it was observed that the studies have sought to identify the key elements that point out the need to hold a family conference, highlighting the 
end-of-life care situations, when the family's doubts and anxieties increase when deciding how to conduct care plans.

Active listening and empathy are therapeutic tools that contribute to the identification and recognition of the need to propose a family conference in the context of patients in palliative care. In the case of end-of-life care patients, the family's concerns, doubts and anxieties are exacerbated ${ }^{(12)}$.At this point it is clinically indicated to hold a family reunion to clarify such doubts and minimize the concerns and anxieties, as well facilitate exchange and joint reflection among the palliative care team and the family, thereby giving them time and space to think, considering the importance of making decisions aligned with the perspectives of each person and the specificities of each situation ${ }^{(16)}$.

\section{Critical attributes or core features of the family confer- ence concept}

The most evident element in the publications that composed the sample was the family meeting to establish care plan. A meeting involving some family members, considering their relationship to the decision-making process and the patient's indication whenever possible; the patient and one or two professionals of the palliative care team, among whom the nurse has almost always been present, considering her/his participation for most of the time in the care delivery. This meeting is a time to discuss the disease, the response to treatment, and the patient's plans and expectations ${ }^{(7,13)}$. It should be noted that the family conference is not an occasion for family therapies ${ }^{(7)}$. Nonetheless, it is an opportunity for the patient and the family to share their concerns, ask questions, raise doubts about the dying process and death, as well as provide information that may contribute to the individualization of care ${ }^{(15)}$.

The family reunion as an essential attribute of the family conference enables to emphasize this concept as a therapeutic intervention strategy that allows patients and families to express their ideas, clarify and validate information in an interactive process of communication among team, patient and family, as well guide the individualized assistance, based on the identification and validation of needs, especially through appropriate questioning and use / understanding of non-verbal signals ${ }^{(3-4,7,13-14,16-20)}$.

Thus, it can be affirmed that the family conference is a valuable clinical intervention, mainly present in the context of Intensive Care Units (ICUs) ${ }^{(13-14,19-20)}$ and aimed at both by professionals and patients in the event of a life-threatening illness or end-of-life care, positively impacting the care practices of these patients, as evidenced by a prospective study using video recordings during 24 family conferences held at two ICUs in Southern California ${ }^{(13)}$.

Family meetings are recognized as a working tool for palliative care staff to support families and maximize the success of their interventions proposed by the palliative care team. It reveals itself as a useful therapeutic tool for information sharing and care planning, with evidence of efficacy in daily clinical practice ${ }^{(12,15)}$.

In order for the family conference to be considered a therapeutic instrument, a preliminary preparation by the team, including the definition of who will attend the meeting, is essential. People who are actively involved in the care process and have information to contribute should be present. Although patients may sometimes be very fragile to attend the conference, even if limited, their participation is important and should be encouraged ${ }^{(15)}$.

The "communication method" attribute shows the possibility of the attributes "information conveyance" and "information sharing" to provide relevant clarifications by the palliative care team about care planning, for the patient and his / her family, at the time that it is possible to share impressions in order to better understand family dynamics, expectations and what the patient thinks about his / her dying and death process ${ }^{(7,16)}$.

In interdisciplinary team work, all professionals - not just physicians - must be able to support the family and pass on information to them. It is important that the news delivered be previously agreed upon by the team and that all professionals be committed prioritizing the patient's wellbeing ${ }^{(15)}$.

The prior planning of the family conference is an essential item that demonstrates the team's interest in the situation, appreciation and respect for the family ${ }^{(17)}$. This planning should include the preferred points to be discussed, taking into account the values of each family and also the possibilities of unforeseen events that may arise during the meeting. In the care plan, the wishes of the patient should be considered, including in relation to postmortem issues. Moreover, it should entail the purposes for an upcoming family conference, as well as the need to be explain how the family can contact the health if there is any post-conference discomfort ${ }^{(8,12,17)}$.

In summary, the family conference involves a plan, a specific content, the definition of duration time, location and participants, so as to meet the demands of each patient and family ${ }^{(3-4,7,13-15-20)}$.

\section{Consequents of the "Family conference" concept}

Among the elements highlighted in this category, the consequent ones generated by the family conference in the context of palliative care refer to a central principle thereof: communication. The literature highlights two main factors resulting from the family conference: effective communication ${ }^{(3-4,7,18-20)}$ and the consensual establishment of an action plan ${ }^{(3-4,12,15-16)}$.

It is inferred that, given the expressiveness of these consequents, they are related to the tripod that integrates the possibility of providing palliative care: patient, family and team. And, in addition to symptom control, the main needs of patients and families are focused on the area of communication, being the effective communication in the quality of care received recognized ${ }^{(3-4,6,20)}$.

Effective communication is a goal that can be achieved through an approach in which patient-focused recommendations are offered in a planned way and in order to establish and maintain trust and respect for the family ${ }^{(18)}$. Therefore, communication among team, patient and family becomes effective when there is consistency and understanding of the facts, it is frequent and timely, honest, true and, above all, focused on the central objective of the care plan, which is respect to the patient's autonomy ${ }^{(17,19)}$.

It is important to note that there is a difference between an informal family communication, which can occur spontaneously at the bedside, in hospital corridors, in the patient's own home or even by telephone, and formal family communication, which must occur within the setting of a family conference $^{(17)}$. 
Concerning the consequents identified in the studies that are related to the patient, "improvement in the quality of care"(8) and "promotion of active listening"(19) are results expected to be achieved after a family conference, with the implementation of an individualized plan of care, taking into consideration the values and preferences of the patient and also the quest to maintain his/her comfort and dignity. It is a delicate balance, both emotionally and cognitively, but essential for promoting care for a worthy death. It is worth mentioning the need for adjustments in the care plan, according to the evolution of the clinical picture and its acceptance by the patient ${ }^{(19)}$.

The consequents related specifically to the family focus on the "clarification of doubts"(13,17), the "family's trust in the team" ${ }^{\prime(3-4,18)}$ and the "family's comfort and tranquility "(8) by feeling part of the process and confident that their loved one is being cared for with dignity and respect. The elucidation of doubts and the credibility of the team's work can result in the possibility of home care for those families who choose to care for their terminally ill patients at home.

In the context of ICUs, family conferences are increasingly important in the planning of end-of-life care, considering that many patients in this situation lose their decision-making capacity ${ }^{(21)}$. Studies ${ }^{(17,20)}$ about family conference in the ICU show that there is an average reduction of one day in the length of stay of the patient in the service after the use of this therapeutic intervention.

The family conference, understood as a therapeutic strategy, together with the possibility of integrating family members, can make communication clearer and develop, in them, greater confidence in the team, besides influencing the patient's adherence to therapy and improving the control of symptoms, thereby providing measures that will reduce the suffering experienced by all ${ }^{(15,17)}$.

Related to the team, the following consequents were evidenced: possibility of identification of needs ${ }^{(3-4)}$; of knowing the clinical history ${ }^{(14)}$ and of being empathic in relation to the patient's personality traits and preferences of care $\mathrm{c}^{(14)}$.

Obtaining data that allow broader knowledge about the patient's life, intra-family relationship, preferences and values allows for greater interaction between the team and the care unit (patient and family), as well as enables not only an effective and efficacious care plan, but also the promotion of greater family trust in the palliative care team ${ }^{(3-4,14)}$. Studies ${ }^{(20)}$ in the intensive care setting have demonstrated the benefit of a family conference also for hospital administration.

\section{Limitations of the study}

Given the small number of empirical studies about the application of the family conference in the context of palliative care, it is possible to recognize the need for investments in the conduct of future research about the problem.

Another possible limitation regards the option of not including the methodological steps related to the use of the concept and the elaboration of the model case, which may be the proposal of a new study.

\section{Contributions to the area of nursing and health care}

The relevance of this concept analysis is the synthesis of the critical attributes and the identification of the antecedents and consequents of the concept of family conference in the context of palliative care. That will allow the palliative nurses the operationalization of this phenomenon as an essential therapeutic intervention for effective communication and management of conflicts in the family context, and even between patient / family and team, thereby contributing to the quality of care and, especially for a death with dignity and a normal mourning for the relatives.

\section{FINAL CONSIDERATIONS}

The analysis of the concept of family conference in the context of palliative care, based on the Walker and Avant model, enabled a closer approximation to the theme, combined with the expansion of knowledge through the determination of critical attributes and identification of antecedents and consequents of the concept, its evolution and its efficacy and effectiveness as a therapeutic intervention, despite the scarcity of publications about the results of its use and the limitation of the empirical studies to the context of patients admitted to the ICU.

It is worth noting that the publications are restricted to European countries, where protocols exist to guide the development of a family conference, as a working tool of the palliative care team. There is a need for more in-depth studies about the understanding of the concept, especially in the area of Nursing, since the literature that deals with the subject is rather scarce, only highlighting studies under the perspective of medical professionals, despite the caveat and recognition that the nurses' performance and presence are important during the family conferences, considering that they are the professionals who have most acted as a case managers.

This study made it possible to verify that it is still necessary to carry out new investigations in order to expand the environments in which the family conference should be present in the context of palliative care, be it in the palliative care units, in the outpatient service, home care services, or in primary health care, not being, therefore, restricted to the ICU environment, as it appears in the empirical studies analyzed.

\section{REFERENCES}

1. Silva RS, Silva MJP. Enfermagem e os cuidados paliativos. In. Silva RS, Amaral JB, Malagutti W. Enfermagem em cuidados paliativos para uma boa morte. São Paulo: Martinari, 2013.

2. World Health Organization (WHO). Definition of Palliative Care [Internet]. Geneva; 2015 [cited 2015 May 13]. Available from: http://www.who.int/cancer/palliative/definition/en

3. Galriça Neto I. As conferências familiares como estratégia de intervenção e apoio à família em cuidados paliativos. Dor[Internet]. 
2008 [cited 2016 Dec 12];16:27-33. Available from: http://www.aped-dor.org/images/revista_dor/pdf/2008/n3.pdf

4. Galriça Neto I, Trindade N. Family meetings as a means of support for patients. Eur J Palliative Care [Internet]. 2007 [cited 2015 May 15];14(3):105-8. Available from: http://www.haywardpublishing.co.uk/ejpc_.aspx

5. Luckett1 T, Phillips J, Agar M, Virdun C, Green A, Davidson PM. Elements of effective palliative care models: a rapid review. BMC Health Serv Res[Internet]. 2014[cited 2015 May 10];14:1-22. Available from: http://www.biomedcentral.com/1472-6963/14/136

6. Araújo MMT, Silva MJP. Communication strategies used by health care professionals in providing palliative care to patients. Rev Esc Enferm USP [Internet]. 2012 [cited 2015 May 15];46(3):626-32. Available from: http://www.scielo.br/pdf/reeusp/v46n3/en_14.pdf

7. Fineberg IC. Preparing professionals for family conferences in palliative care: evaluation results of an interdisciplinary approach. J Palliat Med[Internet]. 2005 [cited 2015 May 20];8(4):857-66. Available from: http://online.liebertpub.com/doi/pdfplus/10.1089/ jpm.2005.8.857

8. Hudson P, Quinn K, O'Hanlon B, Aranda S. Family meetings in palliative care: multidisciplinary clinical practice guidelines. BMC Palliative Care [Internet]. 2008[cited 2015 May 15];7:1-12. Available from: http://www.ncbi.nlm.nih.gov/pmc/articles/ PMC2542352/pdf/1472-684X-7-12.pdf

9. Fernandes MGM, Nóbrega MML, Garcia TR, Macedo KNF. [Conceptual analysis: methodological considerations]. Rev Bras Enferm [Internet]. 2011 [cited 2015 May 15];64(6):1150-56. Available from: http://www.scielo.br/pdf/reben/v64n6/v64n6a24. pdf Portuguese

10. Walker LO, Avant KC. Concept analysis. In: Walker LO; Avant KC. Strategies for theory construction in nursing. 5. ed. Pearson; 2011. p. 157-79.

11. Soares CB, Hoga LAK, Peduzzi M, Sangaleti C, Yonekura T, Silva DRA. Integrative review: concepts and methods used in nursing. Rev Esc Enferm USP [Internet]. 2014 [cited 2015 May 15];48(2):335-45. Available from: http://www.scielo.br/pdf/reeusp/ v48n2/0080-6234-reeusp-48-02-335.pdf

12. Hudson P, Thomas T, Quinn K, Aranda S. Family meetings in palliative care: are they effective? Palliat Med[Internet]. 2009 [cited 2015 May 15];23:150-7. Available from: http://pmj.sagepub.com/content/23/2/150.long

13. Fineberg IC, Kawashima M, Asch SM. Communication with families facing life-threatening illness: a research-based model for family conferences. J Palliat Med [Internet]. 2011 [cited 2015 May 15];14(4):150-7. Available from: http://online.liebertpub.com/ doi/pdfplus/10.1089/jpm.2010.0436

14. Curtis JR, Engelberg RA, Wenrich MD, Nielsen EL, Shannon SE, Treece PD, et al. Studying communication about end-of-life care during the ICU family conference: development of a framework. J Crit Care[Internet]. 2002 [cited 2015 May 15];17(3):147-60. Available from: http://www.ncbi.nlm.nih.gov/pubmed/12297990

15. DeLisser HM. How I conduct the family meeting to discuss the limitation of life-sustaining interventions: a recipe for success. Blood[Internet]. 2010 [cited 2015 May 15];116(10):1648-54. Available from: http://www.bloodjournal.org/content/ bloodjournal/116/10/1648.full.pdf?sso-checked = true

16. Joshi R. Family meetings: an essential component of comprehensive palliative care. Can Fam Phys [Internet]. 2013 [cited 2015 May 15];59:637-9. Available from: http://www.ncbi.nlm.nih.gov/pmc/articles/PMC3681449/pdf/0590637.pdf

17. Moneymaker k. The Family Conference. J Palliat Med[Internet]. 2005 [cited 2015 May 15];8(1):157. Available from: http://online. liebertpub.com/doi/pdf/10.1089/jpm.2005.8.157

18. Gay EB, Pronovost PJ, Bassett RD, Nelson JE. The intensive care unit family meeting: making it happen. J Crit Care[Internet]. 2009 [cited 2015 May 15];24(4):629.e1-12. Available from: http://www.ncbi.nlm.nih.gov/pubmed/19327312

19. Powazki R, Walsh D, Hauser K, Davis MP. Communication in palliative medicine: a clinical review of family conferences. [Internet]. 2014 [cited 2015 May 15];17(10):1167-77. Available from: http://online.liebertpub.com/doi/pdf/10.1089/jpm.2013.0538

20. Sullivan SS, Silva CFR, Meeker MA. Family meetings at end of life: a systematic review. J Hosp Palliat Nurs[Internet]. 2015[cited 2016 Dec 12];17(3):196-205. Available from: http://www.medscape.com/viewarticle/845094_3

21. Rabow MW, Hauser JM, Adams J. Supporting family caregivers at the end of life: "they don't know what they don't know". J Am Med Assoc[Internet]. 2004 [cited 2015 May 15];291(4):483-91. Available from: http://www.ncbi.nlm.nih.gov/pubmed/14747506 